\title{
Espectros na máquina de morar
}

Specters in the machine for living in

para Flávio R. Kothe

\section{Fernando Freitas Fuão}

Fernando Freitas Fuão. Doutor em arquitetura pela ETSA/Barcelona e Pós-doutor em Filosofia pela UERJ, professor titular do Departamento de Arquitetura e do Programa de Pesquisa e Pós-graduacao em Arquitetura, Pesquisador do CNPQ, Líder dos grupos de pesquisa "Arquitetura, Derrida e aproximaçōes" e "Galpōes de reciclagem: Arquitetura Educação e Design".

fuao@ufrgs.br

\section{RESUMO}

O artigo revisita a modernidade desde a ótica dos espectros. A 'hontologia' proposta por Jacques Derrida em seu livro Espectros de Marx (1993) se apresenta como o estudo desse outro totalmente diferente e inesperado. Evidencia a obsessão de um higienismo dos espectros e fantasmas feito pelo Movimento Moderno, o desconjuro da modernidade. Tem como entrada o estudo dos deuses lares da antiguidade greco-romana e as atuais relações com o morar.

Palavras-chaves: Jacques Derrida. Espectros. Le Corbusier. Deuses lares. Domesticação.

\section{ABSTRACT}

The article revisits modernity from the point of view of specters. The 'hontology' proposed by Jacques Derrida in his 1993 book Specters of Marx is presented as the study of this totally different and unexpected other. It shows the obsession of a hygienism of specters and ghosts made by the Modern Movement, the exorcism of modernity. It has as input the study of the Lares gods of Greco-Roman antiquity and the current relations with the practice of living.

Keywords: Jacques Derrida. Specters. Le Corbusier. Deuses lares. Domestication. 
Falarei de espectros e fantasmas, articularei com a tarefa de implicá-los com a temática desse IV Simpósio do Núcleo de Estética Hermenêutica e Semiótica: Arte, Crítica e Liberdade ${ }^{1}$.

Palestra apresentada no IV Simpósio do Núcleo de Estética Hermenêutica e Semiótica: Arte, Crítica e Liberdade, realizado em 19 a 22 de novembro de 2018, no Programa de Pós-Graduação da Faculdade de Arquitetura da UnB.

Minha fala estará apoiada no filósofo Jacques Derrida que escreveu Espectros de Marx em 1993, escrito três anos depois da queda do Muro de Berlim. Derrida nesse livro retornava à fenomenologia para trazer o tema dos espectros, sua importância e implicação nos discursos contemporâneos, como o fim da história e, sobretudo, uma revisão dos marxismos desde a ótica dos espectros.

Derrida propôs pensarmos uma hontologia $(\mathrm{com} \mathrm{H})$, ou seja, a palavra vem do francês hanter (assombrar). Uma hontologia (hauntologia), então, seria o estudo das assombrações, das visitações espectrais, daquilo que retorna sob a forma de herança ou de uma obsessão; uma espécie de "ciência daquilo que retorna". A hontologia seria produzida a partir da leitura dos espectros; diferentemente de uma ontologia (sem H) do ser e sua morada, a hontologia não se deixaria mais capturar pelo estatuto do 'ser' e do 'logos' (ontologia) e sim trataria das aparições, das visitações, das rondas espectrais que habitam de tempos em tempos não só o âmbito político, mas toda a nossa existência.

Quando Derrida abre a questão dos Espectros e passa a considerar os espectros também como um outro (um outro totalmente diferente), ele também está nos induzindo a rever a história, a cidade e a arquitetura pela lógica dos retornantes. Está questionando sobretudo a realidade virtual e os espectros políticos.

Gostaria de mostrar como a questão dos espectros e suas moradas foi retirada repentinamente das casas e de como a modernidade tratou de desconjurar esses espectros presentes não só na arquitetura, mas também nas artes plásticas. Em outras palavras, de como esses espectros subitamente ficaram sem lare de como acabamos por contê-los em estranhos espaços modernos. Na verdade, a modernidade revisitada pela ótica dos espectros revela-se como um projeto louco, pois expurga de dentro das casas modernas todo o reino espectral. Modernidade quer dizer também casas esvaziadas de fantasma e espectros, mas de qualquer forma eles continuam ditando suas regras e nos assombrando todos os dias, só que agora domesticadamente, disciplinarmente.

A hipótese que lanço aqui é que esse desconjuro aos espectros, esse jogo de caça fantasma, Ghost buster, de despejá-los das moradas e de outros lugares que habitavam até ao final do século XIX faz parte de um projeto maior que vem ao longo da história. A partir da segunda metade do século XIX se estabeleceu uma ideia de higienização do mundo, justificada principalmente pelo combate à peste e ao correspondente projeto de domesticação do ser humano. Esses fatos culminaram nos acontecimentos da Primeira e Segunda Guerra Mundial e do holocausto judeu, guerras que devem ser entendidas como higienização do mundo e purificação de raças.

As expressões das vanguardas do início do século XX no mundo da arte e da arquitetura são muito representativas, basta ver as palavras: purismo, suprematismo, dadaísmo, construtivismo e futurismo. É importante aceitar que a arquitetura e a arte estão implicadas nesse processo de higienização física e espectral, no desconjuro e escamoteamento de que não existem fantasmas.

Derrida, ao referir-se aos espectros, não cansará de reiterar o tempo inteiro uma passagem de Shakespeare em Hamlet: "the time is out of joint", isso pode significar: o tempo está fora dos eixos, o tempo está fora dos gonzos (dobradiças da porta), o mundo está às avessas. Sua interpretação é que esse tempo está mesmo desconcertado, está fora de seu próprio tempo. 0 mundo está fora dos eixos, está fora de si. Esse time, para Derrida, também se refere à história e ao mundo. E quando o tempo parece estar desajustado; quando as coisas, a história e o próprio tempo parecem querer retornar a outro tempo é porque um espectro ou vários espectros, ou melhor dito, os retornantes, já retornaram, já estão aqui e agora, há algum tempo nos observando e nos obsidiando.

Diz Derrida que "Tudo começa pelo aparecimento do espectro", mas talvez fosse melhor dizer: "na modernidade tudo começa pelo desaparecimento dos espectros, dos fantasmas, dos espíritos, das superstições". É impossível, entretanto, desaparecer com eles. Talvez possamos falar de substituições, de substituições de uns espectros por outros. Tudo começará com a remoção, com a demolição das casas e dos bairros; tudo começará do novo. Tudo é uma questão de higienização, limpeza. Limpar, limpar até clarear, separar, esquadrinhar, controlar, domesticar, para evitar a contaminação; separar os vivos dos mortos, pois estes são altamente contagiosos, incontroláveis e se disseminam rapidamente. Havia um tempo, porém, em que o tempo estava conjunto, quando ainda existia uma harmonia entre vivos e 
espectros, entre vivos e mortos. Ainda hoje algumas culturas ancestrais ou indígenas vivem nessa coabitação.

A pergunta que se lança de entrada nessa fala: é possível caçar e domesticar espectros, fantasmas? Sim, para mim sim. Hoje não consigo ver a existência da modernidade sem esse desconjuro, sem a perseguição, a caçada e o aprisionamento dos antigos espectros e espíritos; e é isso que vou tentar convencê-los, aqui. Já sabemos que a modernidade não poderia ter acontecido sem a correspondente domesticação dos corpos; o que não imaginamos é que também aos espectros se aplicou uma espécie de doma fantasmagórica, cujo principal campo de batalha foi justamente o domus, a casa - porque em sua arché o espectro é próprio domus. Na origem do domus estava o espectro esperando. Alguns outros lugares onde os espectros outrora habitavam: os castelos, as ruínas, os bosques, as masmorras, os porões, os sótãos, as escadas.

Se, para o corpóreo, a disciplinaridade dos corpos, o panóptico e os regimes da peste e da lepra, apresentados por Michel Foucault, parecem ter dado resultado para a nossa domesticação, para os espectros, haver-se-ia, pois, de empregar outros dispositivos de doma e de contenção. Seria preciso esvaziá-los de seus topos e, se fosse necessário, acabar com a própria casa, fazer a demolição. A modernidade é mesmo um processo de demolição, de arruinamento.

Tudo, até os antigos e pesados retratos de família, deveriam ser removidos e substituídos por outros sem significação. O mobiliário antigo, por móveis mais confortáveis e da moda. Por trás dessa proposta de trocar o mobiliário antigo por móveis mais confortáveis estava o conceito de desimpregnação, que os antepassados deixavam nas cadeiras, mesas, armários, cortinas. Assim como se tratou de substituir todos os lugares de dobras - os esconderijos, as memórias, os baús - como que se mobiliários pudessem servir de abrigo a esses espectros.

Há um escamoteamento da modernidade com relação aos espectros, aos espíritos, às fantasmagorias; eu diria uma certa hipocrisia, no sentido de representação (do grego hypokrinein), pois, ao negar os espectros do passado, ela transformará tudo em fetiche, em mercadoria. Poderíamos dizer que a crise da modernidade é a crise do feitiço, o desencanto. A modernidade é super contraditória. A contradição é uma característica dela própria. O
Figura 1

Os novos retratos de família. Collage. Fernando Fuão.
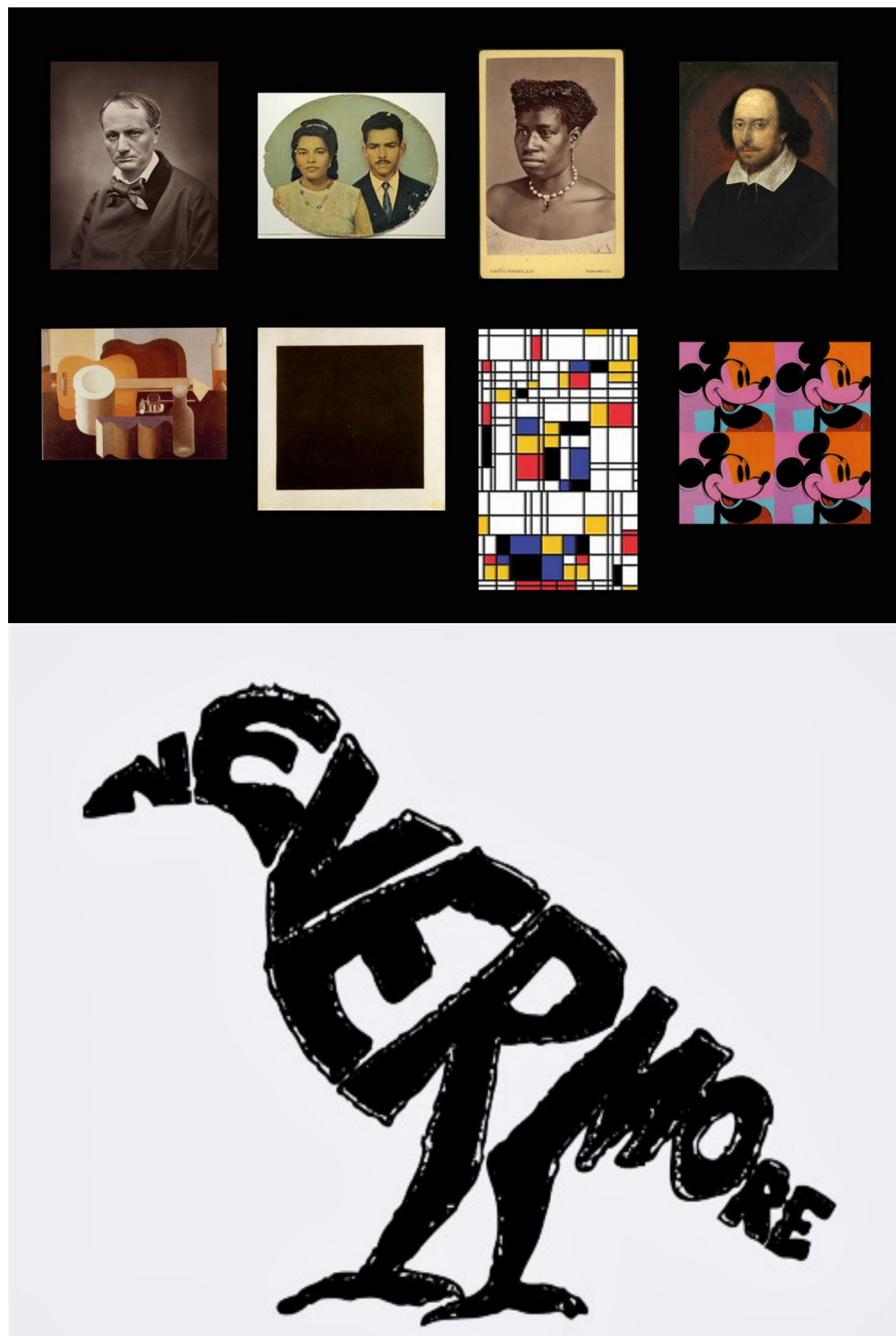

Figura 2

0 corvo de Edgar Alan Poe. 
Entretanto, uma passagem quase obscura, nunca comentada pelos teóricos, que eu saiba, me chamou atenção exatamente pelo tema dos espectros. Nas primeiras páginas Le Corbusier lança uma espécie de desconjuro aos 'deuses lares' - também chamado deuses domésticos entendido aqui como os antepassados - e toda sorte de espectros e superstições enquanto obstáculos à impregnação da modernidade. Em outras palavras: ele desconjurava os espectros tal qual o fizeram anteriormente Max Stirner (1845) e Karl Marx (1846).

Le Corbusier também é obsediado, tem uma obsessão, uma hantiase por esses espectros, só que agora para mostrar a existência deles na arquitetura, dentro da arquitetura. Ele queria desvelar os deuses lares, deuses domésticos que ainda no início do século $X X$ permaneciam impregnados nas casas sob forma de sistema de crenças e superstições. Ele tinha defumadores arquitetônicos poderosos para expurgar os espectros e fantasmas das antigas casas e consequentemente viver numa cidade livre das pestes. Diz a passagem:

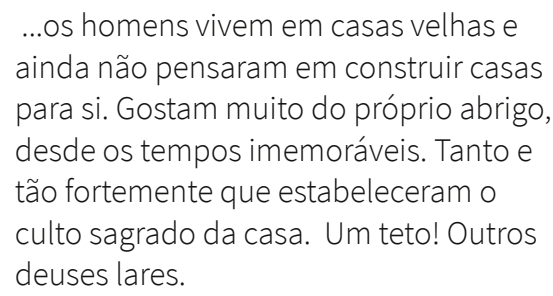

Nem Marx, Engels, Stirner, e tampouco Derrida, nenhum deles, exceto Le Corbusier deu a devida importância à casa, o lar como topos por excelência desses espectros. Não há como ignorar esse fato. De alguma forma, o estudo dos espectros, uma hontologia derridiana, passa inevitavelmente pela questão da morada, do lar, no culto dos deuses lares, os topos e tropos desses espectros. O corvo estava repleto de razão.

Enfim, na questão da terra, da casa, da propriedade privada está o tema dos espectros. No chão, está enterrada e encravada a própria morte. Nas fundações das casas das cidades estavam os mortos, os antepassados, que continuavam vivos, mesmo enquanto mortos. É o espectro que funda o oikos, a oikonomia, o domus, o processo de domesticação sobre os familiares, assim também como a lei da hospitalidade do espectro, que ali aguarda em seu interior sem interior os hóspedes e os sucessores da família, os que estão por vir. Esse sistema de crenças criava um lugar todo especial: o lugar do encontro, da simultaneidade dos vivos com os mortos, dos mortos que ali permaneciam protegendo os vivos, numa coabitação, numa comunidade, numa comum unidade de vivos e mortos.

Quem eram os 'deuses lares' que Le Corbusier desconjurava em Por uma arquitetura? Fustel de Coulanges em seu livro A cidade Antiga (1864) explica detalhadamente sobre a origem e significado da palavra Lares, a qual está diretamente associada ao fogo sagrado. Para Coulanges, os deuses lares eram literalmente os mortos, os antepassados de cada família que os vivos cultuavam como deuses, geração após geração. $\mathrm{E}$ cada família tinha os seus respectivos deuses lares. o lar era o fogo sagrado que representava os mortos, todas as casas dos gregos ou dos romanos possuíam um altar, um lararium, e neste altar devia haver sempre restos de cinzas e brasas. Era obrigação sagrada do dono, o 'dom' (domus) de cada casa manter o fogo acesso dia e noite. $O$ fogo só deixava de brilhar sobre o altar quando toda família havia morrido; quando não havia mais ninguém para mantê-lo aceso. Lar, larariun extinto, significava família extinta.

Portanto, aqueles a quem os antigos chamavam deuses lares, deuses domésticos, eram somente as almas dos mortos, aos quais o homem atribuía um poder sobre-humano e divino. Posteriormente, o cristianismo condenaria como uma forma de paganismo (de paganus que quer dizer simplesmente colono). Essas almas humanas divinizadas pela morte os gregos chamavam de demônios ou heróis. Os latinos, por sua vez, nominavam lares, manes, penates e gênios. Os lares, portanto, eram os deuses vivos protetores das casas e da família.

A religião dos mortos, não se constituía somente em um culto aos mortos, mas simultaneamente numa religião ditada pelos mortos, um nomos, uma lei que organizava a vida dos vivos. Esses mortos pareciam estar mais vivos ainda do que quando vivos; enquanto mortos, ditavam ainda suas leis, sua moral, suas maldições e conjuros, caso não se cumprissem seus desejos ditados enquanto vivos.

O morto, ao sangrar a terra, a consa(n)grava, e assim a terra não podia mais ser vendida. Vender a terra
Le Corbusier Por uma arquitetura. São Paulo. 1983.

Editora Perspectiva p.5 No original: "Mais les hommes vivent dans de vieilles maisons et ils n'ont pas encore songé à se construire des maisons. Le gîte leur tient au cœur, depuis tous les temps. Tant et si fort qu'ils ont établi le culte sacré de la maison. Un toit! autres dieux lares (gf. nosso). Les religions sont établies sur des dogmes, les dogmes ne changent pas; les civilisations changent; les religions s'écroulent vermoulues. Les maisons n'ont pas changé. La religion des maisons demeure identique depuis des siècles. La maison s'écroulera."Le Corbusier. Vers une architecture. 2.ed. Les Éditions G. CRÈS, 1924, Paris, p. 6. 


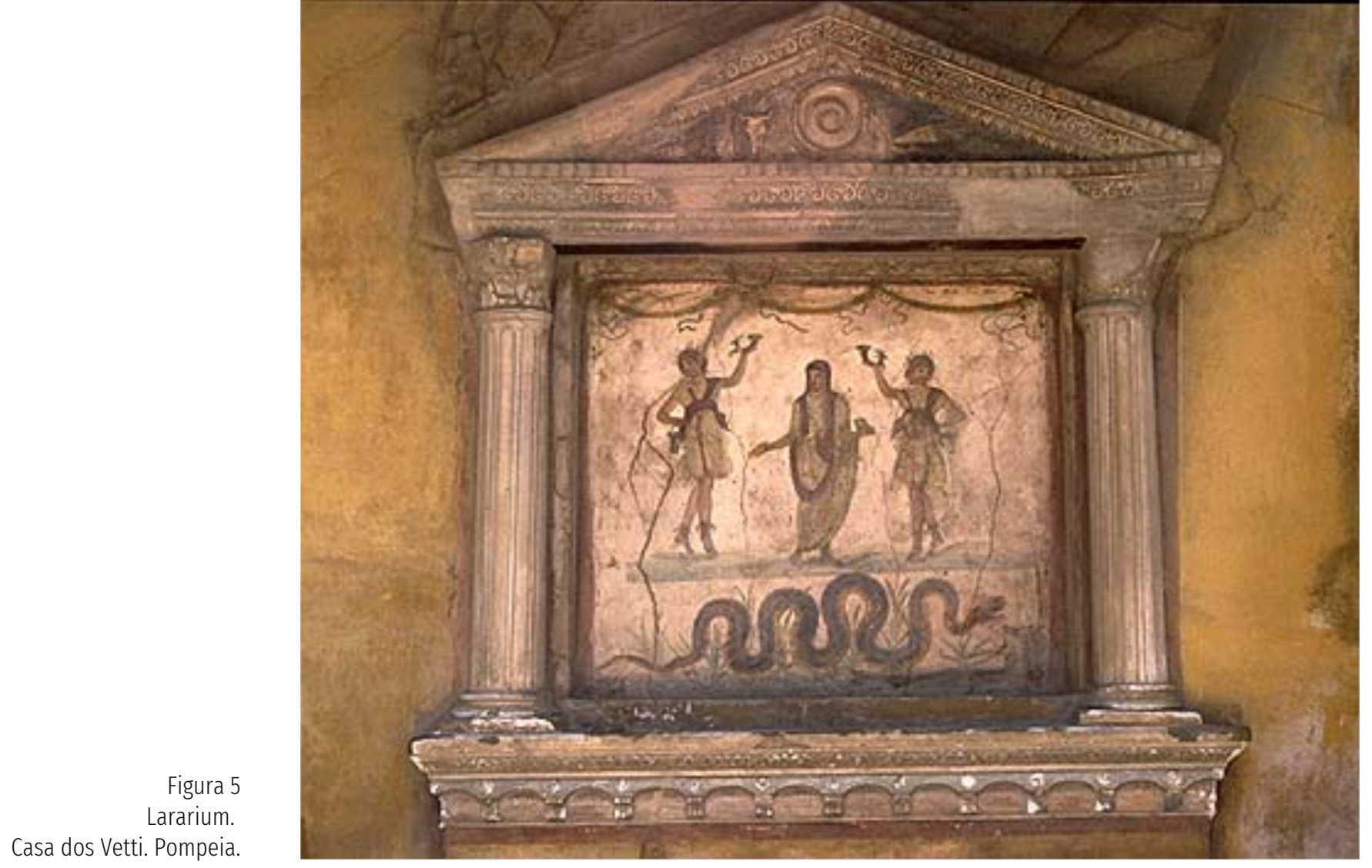

4

Coulanges explica que mais tarde ainda, desse culto ao fogo sagrado, deuses lares, se criou a grande o culto

da deusa Vesta (nome grego que designava 0 altar com o fogo

sagrado). Vesta surge como deusa virgem, não representa nem a

fecundidade nem o poder, mas a ordem; não a ordem rigorosa, abstrata matemática, mas sim a ordem moral.

Na grécia era conhecida como Héstia. A grosso modo, quando se estabelece o culto a deusa Héstia, similarmente a Vesta em Roma, se

estabele a criação das cidadeestados na Grécia; esse momento

representa o primeiro intento de unificar todos os distintos cultos aos

deuses lares praticados em cada casa. Assim, cada cidade-estado grega passa a ter uma lareira comum com um fogo sagrado no edificio principal, onde os convidados se reuniam oficialmente; e cada colônia levava o fogo sagrado de sua cidade natal para acender o fogo da nova cidade. Quando um casal se unia, a mãe da noiva acendia uma tocha em sua casa e a transportava diante do casal recentemente casado até sua nova casa, para que acendessem a primeira chama em seu lar. Este ato consagrava o novo lar. significava vender seus antepassados e perder sua proteção. Abandonar a terra significava tornar-se um errante, um desterrado, significava perder sua referência no mundo, seu centro, seu sentido de existência, pois naquela época cada domus era o centro do mundo. Essa morada da família, na antiguidade, nunca era passível de venda, ela não era e nunca poderia ser uma mercadoria, como hoje entendemos.

Para Coulanges, havia três coisas que, desde os tempos mais antigos das culturas gregas e itálicas, andavam inseparáveis: a religião doméstica (os lares), a família e o direito da propriedade. Hoje, para nós, seria o correspondente à tradição, família e propriedade, a TFP. $O$ culto aos deuses lares constituiu não só a ideia das famílias gregas e romanas, mas também estabeleceu as regras do casamento, a autoridade paterna e o falocentrismo, consagrando graus de parentesco e o direito sucessório da herança. Nesse culto, podemos afirmar estar enraizado também o sentido de propriedade privada, que era algo bastante distinto do que entendemos hoje da casa como propriedade privada, como mercadoria. Era o morto que garantia a posse da terra ${ }^{4}$.

Na antiguidade, os homens pertenciam à terra e não a terra pertencia aos homens, e a dita 'propriedade' sobre essa terra também pertencia mais aos mortos que aos vivos. Assim, os vivos tratavam de adorar a terra e os mortos em simultaneidade. Havia uma forma de ver o invisível no mundo visível, um modo distinto de tocar e ser tocado por esse mundo espectral, completamente diferente do nosso que vivemos. Não conseguimos ver mais essa invisibilidade. Entretanto, hoje vemos outras estranhas invisibilidades graças aos raios-x, aos microscópios, ao Hubble e a Curiosity.

Até hoje, tanto na língua espanhola como portuguesa podemos observar a persistência secular desse fenômeno, quando conseguimos conectá-la à palavra hogar, que em espanhol designa tanto o lar como a lareira, ou em português, que é o mais óbvio, na palavra lareira que guarda o prefixo 'lar', o lugar do fogo dentro da casa, ou mais atualmente: o celular, o lar dentro do bolso, o fogo na palma da mão.

O fogo dentro da casa, para nossa civilização, já não guarda nenhuma relação com nossos antepassados mortos. Nem tampouco a fumaça, o espiritual que advém dela, nada parece nos conectar com os antepassados. Já não conseguimos ver o fogo que cultuamos na atualidade, ele arde sob a forma de estranha lareira, um lararium midiático sempre acesso, televisivo, do telejornal ou do cell-ular (cell em inglês quer dizer cela) sempre ligado à Matriz. Ao ponto de pensarmos que celular extinto, sem bateria, significa que pode ter acontecido algo trágico com seu dono, seu dom.

Nessas telas aparecem os novos deuses lares em diferentes sintonias. Novos espectros, do tipo Willian Bonner do Jornal Nacional ou Mark Zuckberg do Facebook, que não têm nada a ver com nossos antepassados, mas de alguma forma, a cada vez que 


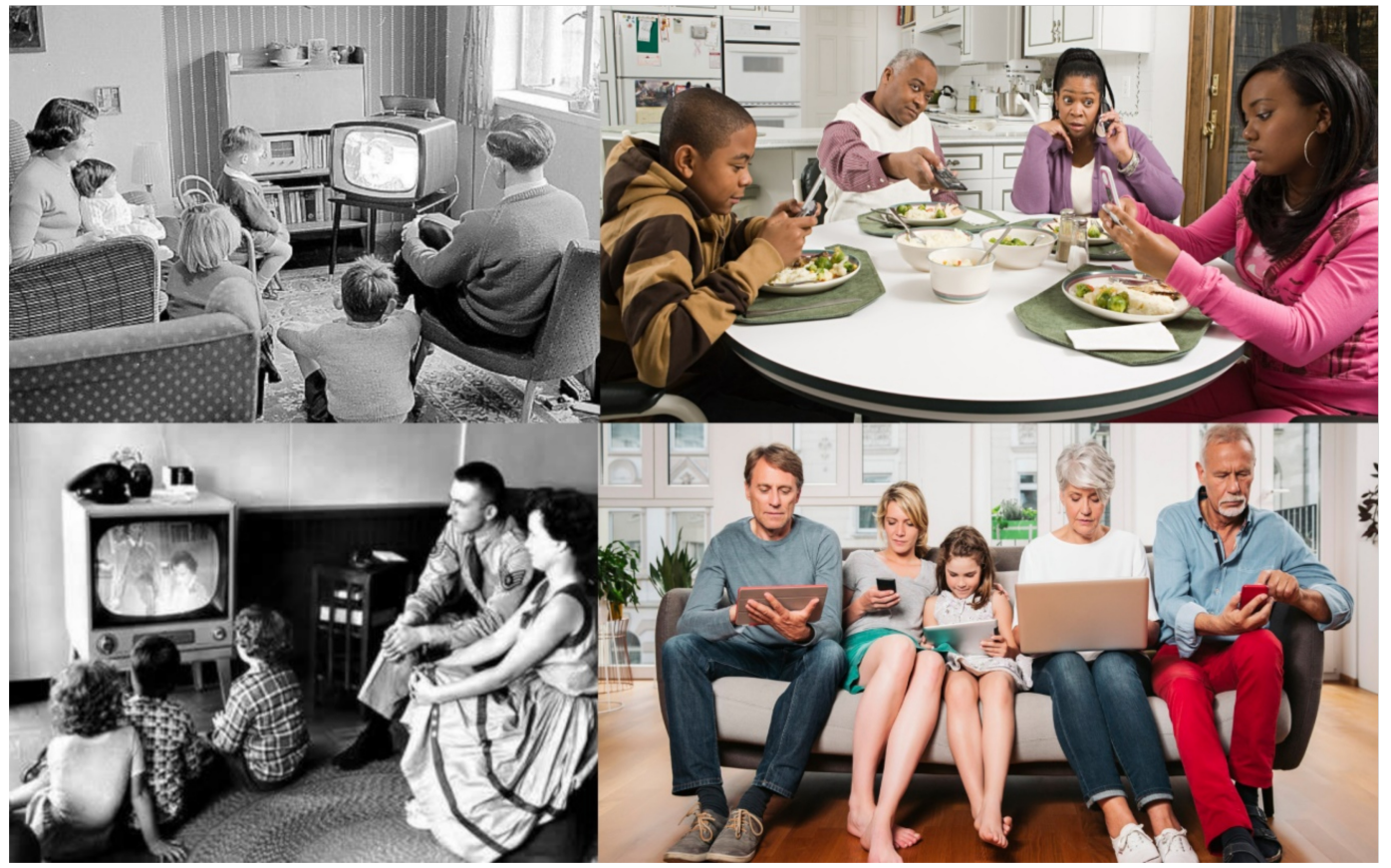

acendemos o fogo, esses espectros ditam suas leis sutilmente pela tela, organizando e reunindo nossas vidas em estranhas comunidades.

O filósofo Peter Sloterdijk mostra-nos a relação direta que existia entre os deuses lares e a importância do nascimento, do ser que está por vir e seu correspondente espectro, a entidade, o duplo, a 'IDentidade'. Numa passagem contida em Esferas 1, Sloterdijk emprega a palavra genius e, como bem sabemos, é a mesma palavra que, para Coulanges, designava os deuses lares (manes, penates e genius).

Diz Sloterdijk: “Todos os partos são partos de gêmeos, ninguém vem ao mundo sem companhia e sem anexo" .

Lembrando que Geminus, em latim, quer dizer dobrado, duplicado, igual. O genius se diz aquele que acompanha a vida de todo indivíduo humano, e por isso lhe rendiam homenagens precisamente a cada aniversário. Gênio é o deus sob cuja tutela vive cada um tão logo nasça. Mas o gênio nos foi colocado ao lado como observador assíduo, de tal modo que não se afasta nem por um momento, e nos acompanha desde a saída do seio materno até o último dia de nossas vidas ${ }^{6}$.

Se chama genius porque seguramente provém de geno (engendrar), porque se preocupa que sejamos engendrados; ou ainda porque é engendrado como nós, ou mesmo, porque nos protege e aceita como engendrados.

Figura 7.

Gary Hill. I Believe It Is an Image in Light of the Other, 1991-92. Mixed media installation. protetor que desde esse dia existiria. Sloterdijk, nos
Exatamente por isso, para os romanos, todo aniversário era duplo; nele não se pensava somente no chamado acontecimento feliz, mas também na conexão indissolúvel entre o indivíduo e o espírito explica que "para os romanos, o princípio da filosofia moderna, cogito ergo sum, 'o penso logo existo' teria sido totalmente incompreensível, porque unicamente esperavam a forma passiva: 'se pensa em mim, logo sou'."7

Os deuses lares, ou o gênio é muito parecido também ao que Heidegger chamou o amigo do Dasein que carregamos dentro; ela não fala mas é a escuta da voz, o próprio amigo que escuta calado, apenas observando, vigiando, ele sempre nos vê, mas estamos impossibilitados de sua visibilidade. Heidegger evocava esse estranho amigo, demonstrando que o dasein nunca está sozinho, não nasce sozinho; é como o nascimento duplo do gênio,

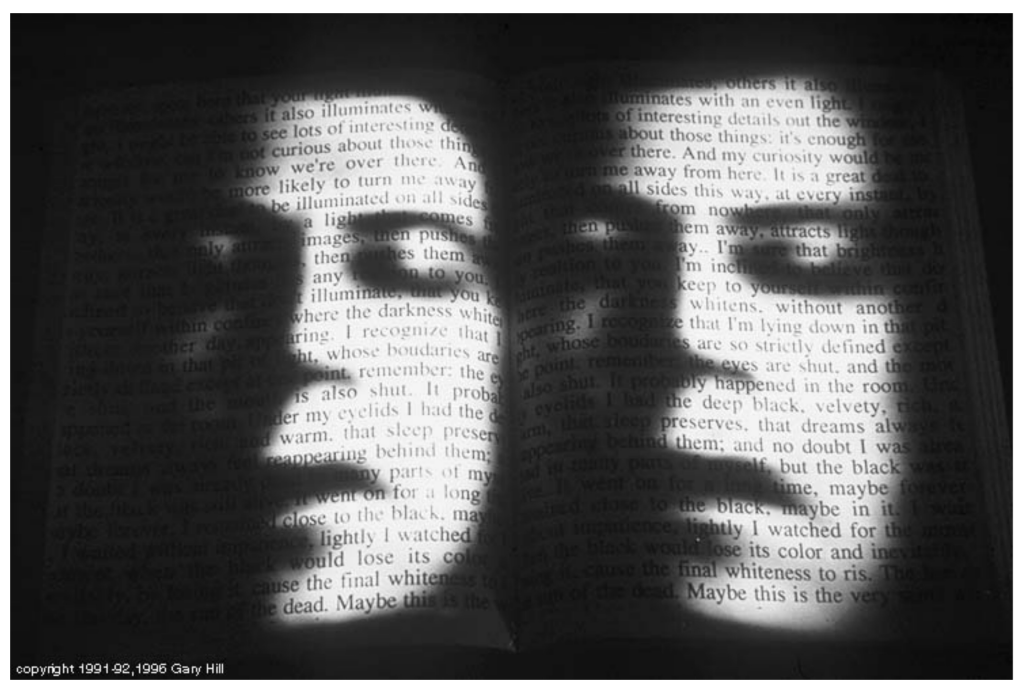

Figura 6

Celul-lares. Collage. Fernando Fuão. 2018

Portanto, onde quer que um novo casal se aventurasse a estabelecer um novo lar, Héstia vinha com eles com o fogo sagrado ligando o lar antigo com o novo.

5

SLOTERDIJK, Peter. Esferas 3.

Espumas, Barcelona, Ed. Siruela, 2003, p. 375

6 Op. Cit.; p. 378

7

Op. Cit.; p. 379 
Veja-se FUÃO, F.; A porta. Em FUÃO, F.; VIECELLI, A.: A porta, a ponte, o buraco, um orelhão,

Coleção Querências de Derrida, moradas da arquitetura e filosofia, Porto Alegre, 2015, UFRGS, CNPq, Capes.

Figura 8 Planos higienistas. Collage Fernando Fuão. 2018.

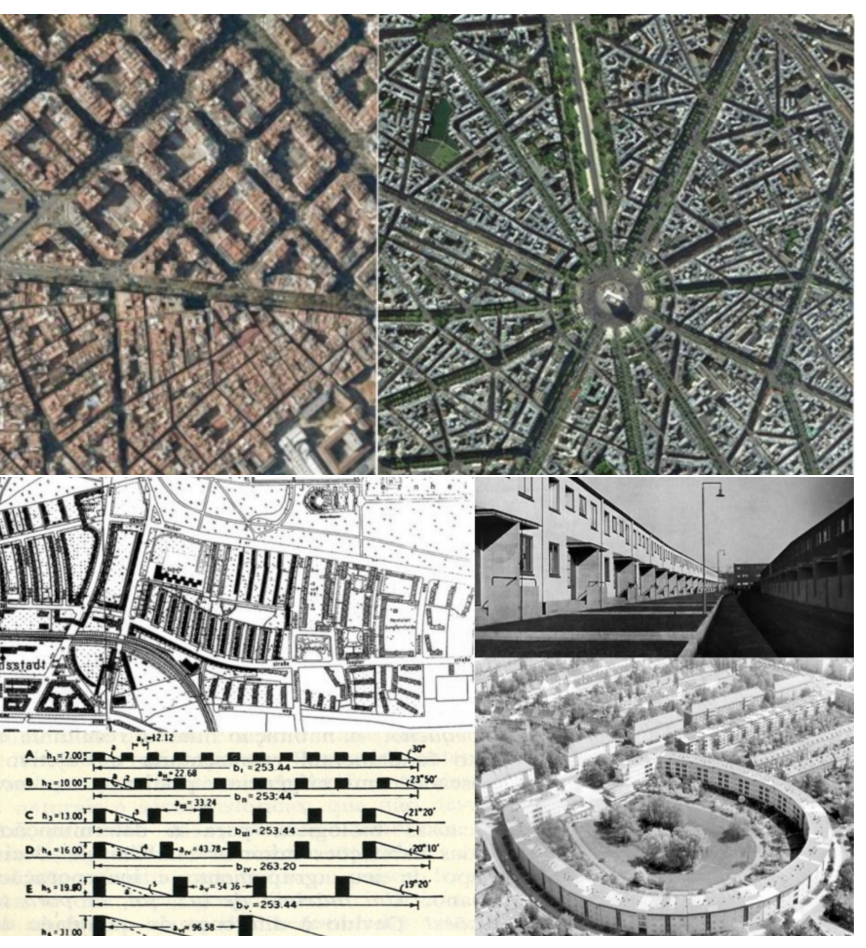

Figura 9

Planos higienistas modernos.

Veja-se a ideia de herência em FUÃO, F.: Querências de Derrida.

Em Arquitetura e Filosofia da

desconstrução, Coleção Querências de Derrida, moradas da arquitetura e filosofia, Porto Alegre, 2015. Ufrgs Cnpq, Capes

Le Corbusier. Carta de Atenas. São Paulo, Hucitec, 1993, p. 59 esse amigo que não está nem dentro nem fora de nós, está dentro e fora, diz-se que está ao lado, mas talvez não está em lugar nenhum. Está na sombra, no umbral, na umbra, na portada ${ }^{8}$.

Não é a casa que engendrava os deuses lares, os gênios, mas sim os que ali morreram e iriam morrer. Parece que o que funda o lar, as fundações, é um pacto prévio do vivo jurando a si mesmo, jurando a esse outro oculto que morrerá ali. São esses espectros que determinarão também a herança, e não há herança, nem 'herência', sem esta certa querência, sem um abraçamento entre mortos e vivos. E na herança sempre há um ato de aceitação ou de rejeição ${ }^{9}$.

Como poderiam tanto Marxe Max Stirner abolir a propriedade privada, sem exterminar com o culto dos deuses lares e sem retirar os cadáveres da casa, da terra? Era preciso acabar com esse sistema de crença que permitia a herança e a perpetuação da terra principalmente da classe dominante, ainda que no século XIXjá não se enterrassem os mortos na propriedade. Ambos sabiam que era impossível passar de uma produção individual para uma produção coletiva sem acabar com a propriedade privada rural e urbana, enquanto os deuses lares asseguravam a propriedade.

Para Le Corbusier ou para o comunismo, a nova cidade higienista, a cidade radiosa, o modelo de cidade do futuro teria que ser uma terra de ninguém, uma terra sem passado, sem espectros, sem fantasmas e também sem muita história para contar. Sim, era preciso caçar, prender esses espectros, tirar a pele deles, de preferência longe da casa, do lar. Lavar a terra de seu sangue. Exumá-los.

A queda da Casa Usher de Edgar Alan Poe pode ser vista como um símbolo da derrocada dos espectros, de sua demolição. Quando cai Usher e sua casa, desaba também o homem doente produzido pela sociedade capitalista que, fraco, quase moribundo, tenta enterrar seus cadáveres, sua irmã, mesmo sabendo que ela pode retornar.
A casa desabará. A modernidade é desabamento sobre desabamento, para poder se manter sempre no presente e no futuro. Diz Le Corbusier na Carta de Atenas: "O obstáculo só poderá ser suprimido pela demolição"10. Arguto como um corvo, ele escolhia suas carniças, os prédios que deveriam ser exumadose removidos, e prossegue: "É possível que, em certos casos, a demolição de casas insalubres e de cortiços ao redor de algum monumento de valor histórico destrua uma ambiência secular. É uma coisa lamentável, mas inevitável"11.

Poderia se dizer que, a partir do século XVIII, se constrói a grande epistéme da higienização e cito aqui alguns eventos: limpeza das línguas, higienização da imagem, formação de uma gramática tanto para a escrita como para a pintura. Higienização essa que terá seu avatar na domesticação humana, na eliminação das diferenças, na transformação dos diferentes em iguais higienizados, branqueados, basta lembrar os clássicos Robinson Crusoé de Daniel Defoe, ou Tarzan de Edgar Rice Burroughs.

Tanto os higienistas quanto os marxistas, na segunda metade século XIX, queriam eliminar a peste e as péssimas condições de habitação na Inglaterra. Para os higienistas, eram necessárias habitações dignas para os operários, higienizar as cidades dos focos de peste e a insalubridade. Era preciso acabar com o foco: o tecido medieval das cidades. Entretanto, a casa dos trabalhadores e dos miseráveis estava, não só infestada pela peste, pela miséria, pelos espectros e superstições, mas também pelos revolucionários comunistas. Era necessário separar as misturas; basta citar o exemplo clássico do Plano Hausmann para Paris, o Ensanche de Cerdá para Barcelona, e as cidades higienistas nas colônias na América do Sul.

O combate à peste, o desejo de higienização do mundo, por incrível que pareça, era consenso entre comunistas e conservadores. O modelo de afastamento dos corpos arquitetônicos, em blocos e barras, vai ser o modelo aplicado desde os primeiros conjuntos habitacionais alemães propostos por Walter Gropius até as proposições modernistas radicais e radiosas de Le Corbusier. Convém lembrar também que a implantação dos grandes conjuntos habitacionais na Rússia na época de Lenin e posteriormente também de Stalin seguiam o mesmo modelo de distanciamento entre os volumes arquitetônicos. Havia uma crença na questão da iluminação e os benefícios da radiação solar que perpassava qualquer ideologia, para acabar com a cidade pestilenta, talvez os mesmos espectros que datavam do iluminismo, dos déspotas esclarecidos. 


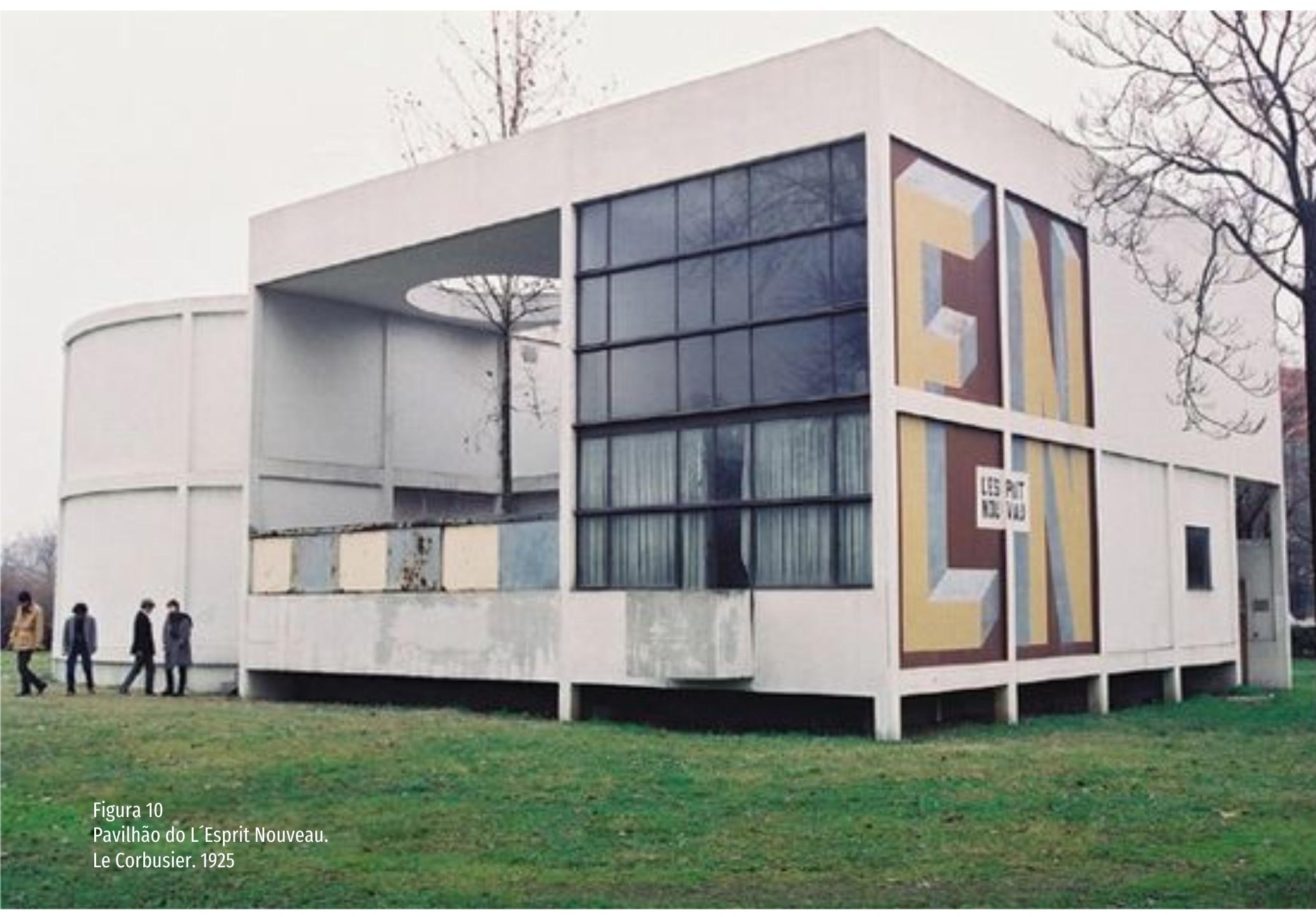

\section{UM ESPÍRITO NOVO APARECE. "L'Esprit Nouveau"-}

O próprio título da revista $L$ 'Esprit Nouveau confirmava a existência de antigos espíritos e propunha a chegada de um novo espírito. Dessa vez puro, esvaziado de qualquer ligação com os espíritos do passado, fantasmagórico, esbranquiçado como que se a cor branca representasse a higienização hospitalar, límpida, translúcida, espectral. Esse Espírito Novo não deveria estar mais vinculado a nada humano. 0 Espírito Novo era uma espécie de novo messias que vinha ao mundo sob a forma de máquina, para redenção do comunismo; vide por exemplo o impacto no campo tanto do trator na revolução soviética e como do rádio na revolução chinesa. Na arquitetura, o Espírito Novo teria sua expressão na casa como máquina para morar. Acreditavase que espectros e fantasmas não poderiam habitar uma máquina.

Certamente, a casa como máquina de morar não era um lugar apropriado para espectros e assim se transformava a nova casa em uma mercadoria, um objeto similar a um automóvel mesmo, serializado e repetido, poluente, esvaziado de toda tradição e da aura. Esse objeto não poderia durar, perdurar várias gerações, era necessário desconjurar os deuses lares, o lar e até a lareira, qualquer coisa que lembrasse o fogo sagrado. O fogo deveria dar lugar a outro tipo de energia, a um novo conjuro. 


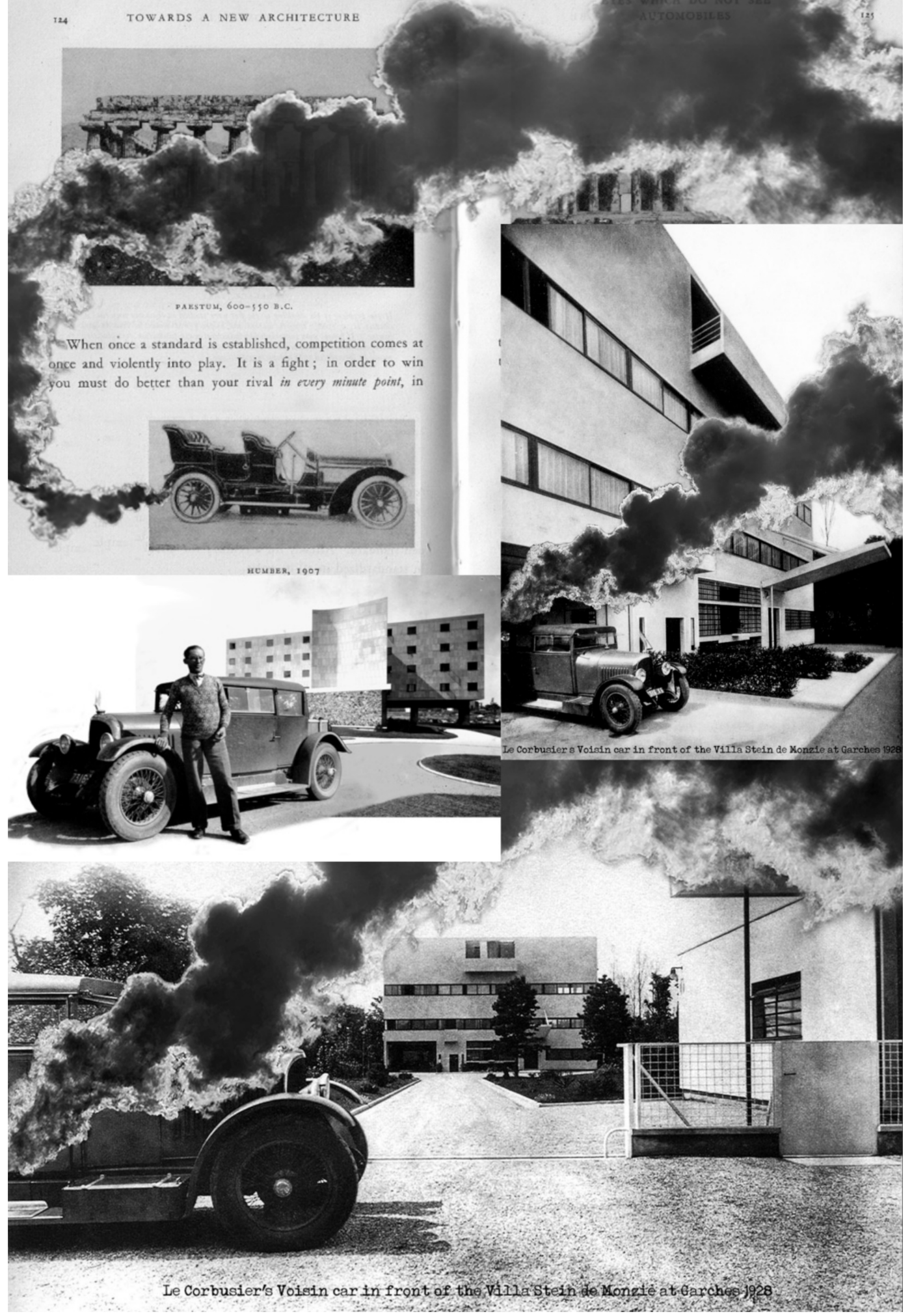

\section{O RADIADOR}

0 fogo na antiguidade sempre estabeleceu uma conversação entre os vivos e os mortos, entre o material e o espiritual. A lareira sempre foi um símbolo dessa possível conversação, mas com o passar do tempo foi perdendo seu sentido de origem e transformou-se hoje na simples lareira, cuja função básica é o aquecimento. Para alguns arquitetos e engenheiros modernos era preciso removê-la das casas por motivos de segurança e de prevenção de incêndios.
Enquanto símbolo de ligação com o passado, elas aparentemente continuavam a representar os deuses lares, a tradição e a arquitetura pitoresca das casas neogóticas.

Para os modernos e modernistas era preciso apagar esse fogo. Le Corbusier, em 1930, fará uma ironia surrealista com a questão da lareira e do lar em seu projeto para o terraço na cobertura da casa Beistegui (1930-31) ao colocar uma falsa lareira no muro ao redor 
do terraço, totalmente aberta e sem cobertura, uma lareira sem chaminé e extremamente ornada, com duas cadeiras uma em frente da outra ao lado. Era preciso substituir o fogo por sistemas de aquecimento mais modernos, higiênicos e eficientes como os radiadores, aquecedores movidos a caldeiras, tal como nos transatlânticos ou nas locomotivas. Certamente, nenhum espectro ou deuses lares poderiam fazer sua aparição ou habitar um radiador metálico.

O radiador irradiava um calor que espantava, exercia uma nova atração. A metáfora da casa como máquina de morar pressupunha obviamente a utilização de máquinas, engrenagens no interior da casa 'máquina para morar'. Máquinas para aquecer, máquinas para resfriar, ventilar, máquinas para lavar, secar, cozinhar. Máquinas para fazer máquinas.

Esse espírito novo se manifestaria na arquitetura, grosso modo, de duas formas fantasmáticas de fetiche: primeiro, através de um branqueamento da arquitetura em suas paredes, interna e externamente, um branco que corresponderia não só à brancura mediterrânea, dos pequenos povoados mediterrâneos, mas também à brancura hospitalar como signo da higienização e limpeza. Esse mito do branco, embora já desmitificado, persiste até hoje no minimalismo, como Affonso Romano de Sant'Anna se referiu em 'A síndrome da marmota'.

A outra forma fantasmática se dá através da transparência promovida pela utilização do vidro, de seus reflexos e espelhamentos como objeto fetiche, como os espelhinhos e coisas que reluzem, os quais os indígenas se veem fascinados, paralisados. Essa retórica também se expressa na arquitetura na metáfora dos Raios-x, onde tudo se pode ver através dele e nada pode se esconder lá dentro. Nesse sentido dever-se-ia também fazer uma espectrografia da obra de Mies van der Rowe.

Entretanto, uma forma fantasmática não excluiria a outra, assim a casa moderna assumiria um mix desses aspectos espectrais. Talvez poderíamos acrescentar uma terceira característica: as superfícies polidas, lustradas, esmaltadas e laqueadas, inspiradas nas pinturas metálicas dos automóveis, aviões e máquinas, que terminariam aparecendo em pisos, paredes e tetos. A porosidade das paredes e suas rugosidades pouco a pouco perderam sua expressão, e consequentemente o brilho passará a ser associado à limpeza, como na caixa de sabão em pó Brillo criada por Andy Warhol.
Figura 12

0 radiador de minha casa. Collage. Fernando Fuão. 2018
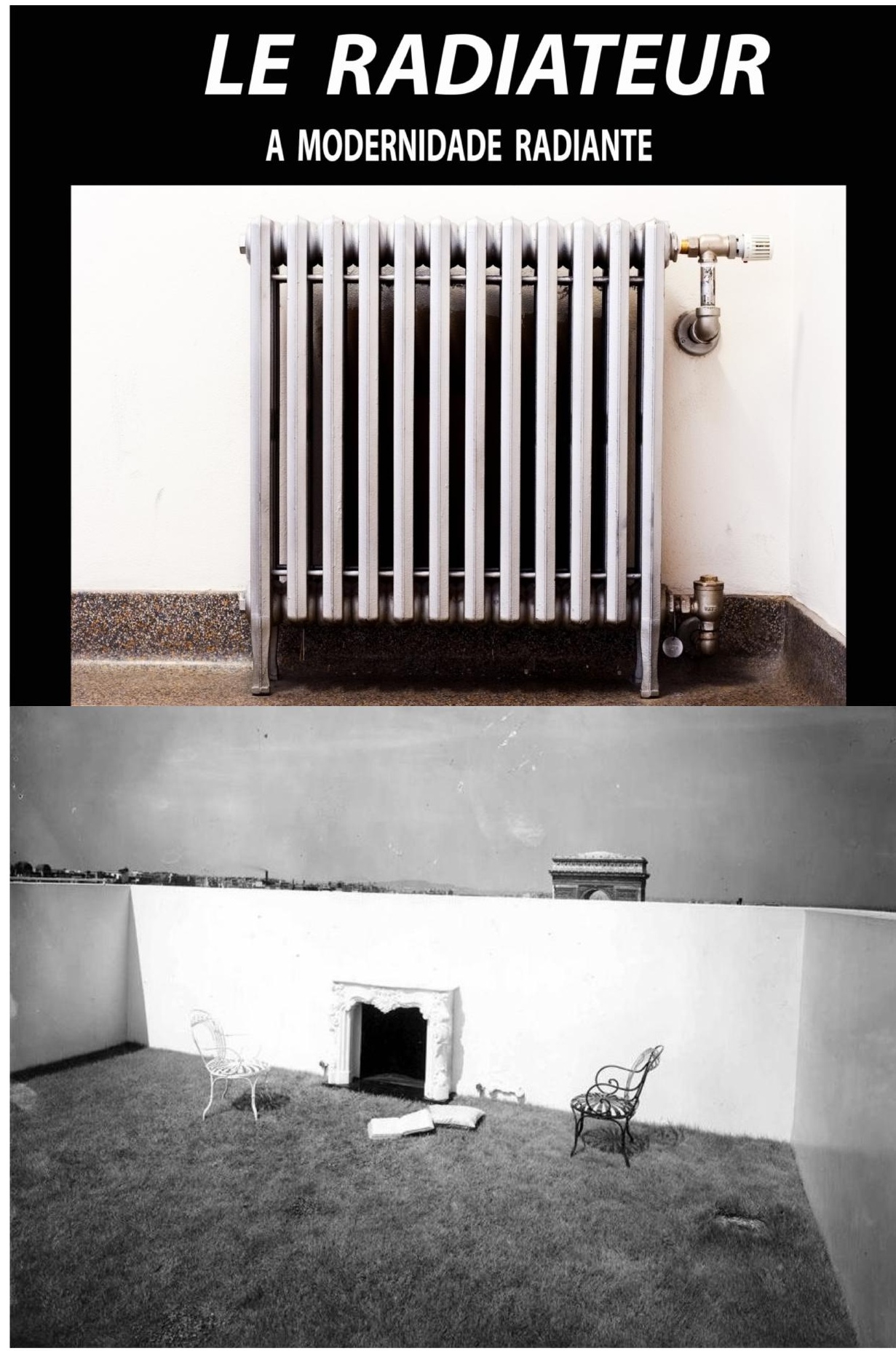

Figura 13

Terraço da Casa Beistegui. 1930-31. Le Corbusier 

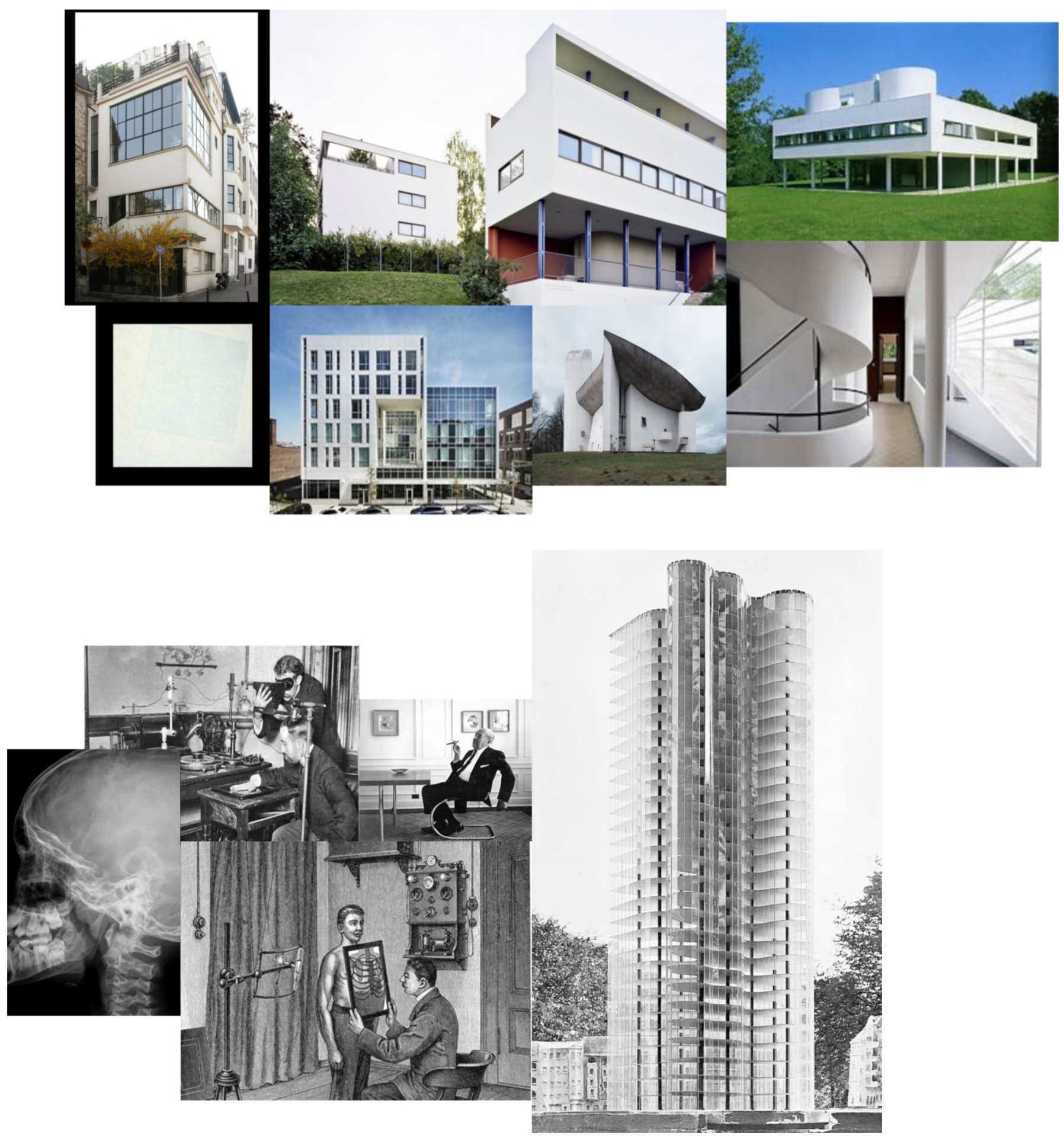

Figura 14 A sindrome das marmotas. Collage. Fernando Fuão. 2018

Figura 15 Arquiteturas radiográficas. Collage. Fernando Fuão. 2018.

Figura 16 Reflexos espectrais. 0 Pavilhão do Mies. Barcelona. 2014

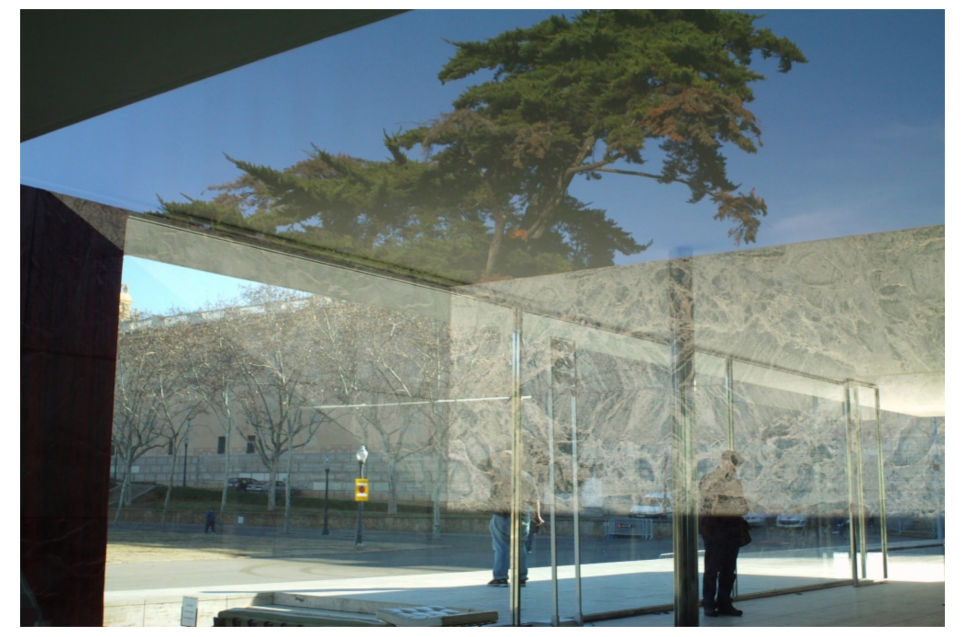


Veja-se a quantidade de desinfetantes, alvejantes, polidores, pasta de dente sob o rótulo de brilho, brilhante, etc ${ }^{12}$.

Esse espírito que habitava as livrarias francesas também foi despachado timidamente como feitiço para o resto do mundo pelos correios, aviões e barcos, Mário de Andrade, por exemplo, colecionava o L'Esprit Nouveau. Espíritos, espectros e fantasmas viajam tanto nos navios como nos aviões, como os negros escravos quando vieram para a América e trouxeram seus deuses, seus antepassados e seus temores. Agora não mais diferentes espíritos, deuses lares, espectros; de agora em diante, um só: o Espírito Novo, Universal.

\section{MODERNIDADE RADIOSA}

A partir do final do século XIX e início do XX, o mundo moderno se radializava num crescendo. 0 radium, 0 ratio passavam a organizar o mundo de uma nova forma: o radial dos motores, o raio das rodas dos automóveis, das engrenagens. 0 radio, o radio portátil (radial), a radiografia, a radioterapia, o sistema de circulação de veículos e suas radiais, raiogramas de Man Ray, a lista é bastante extensa, até chegarmos à radioatividade, a radiação ativa. Se formos buscar uma etimologia certamente cairá no radio elemento químico (RA) e, coincidentemente, na língua egípcia 'RAH' que significa O Deus Sol.

Tudo será radiosamente radioso, ensolarado na modernidade. O Espírito Novo é um espírito radiante, iluminado. Luz, Lux; talvez devessem reconsiderá-los como mais uma revisitação dos espectros do iluminismo.

Le Corbusier cria a Carta de Atenas, um dispositivo de ordenamento e controle das cidades idealizadas. Posteriormente, os postulados serão traslados para o cotidiano da vida através dos Planos Diretores estabelecendo normas de gabaritos de ruas, afastamentos mínimos, alturas, recuos, tudo para estabelecer a iluminação necessária, composição, higiene e saúde, sempre sobre a justificativa da insolação. Entre outras propostas revolucionárias da Carta está o de que toda a propriedade de todo o solo urbano da cidade pertence à municipalidade, sendo, portanto, público, e, nos países comunistas, propriedade do Estado. Tais preceitos influenciaram o ordenamento das cidades europeias após a Segunda Guerra Mundial e a criação do Plano Piloto de Brasília por Lucio Costa.
Le Corbusier acreditava assim como os médicos da época que a helioterapia era uma importante aliada no combate à tuberculose, a tisica. Hoje sabemos que o sol não faz a mínima diferença no tratamento da tuberculose. Eis uma das tantas passagens em que Le Corbusier na Carta de Atenas se manifesta em relação ao sol e à radiação solar:

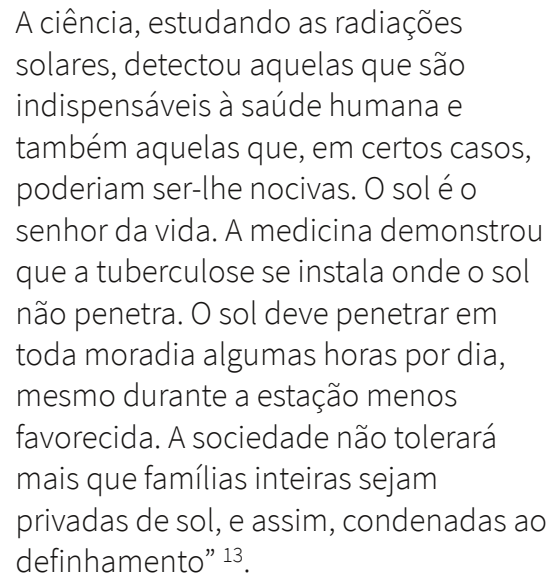

Entre as palavras radieuse (radiante, iluminado, brilhante, brilho) e radiateur (radiador), tanto em francês como em português, há uma estreita relação não só daquilo que brilha como também daquilo que aquece.

Le radieuse e le radiateur. Do latim, radiator, aquele que emite raios, de radius, raio de luz, vara reta, vara de uma roda. O radiador é uma parte do motor que é

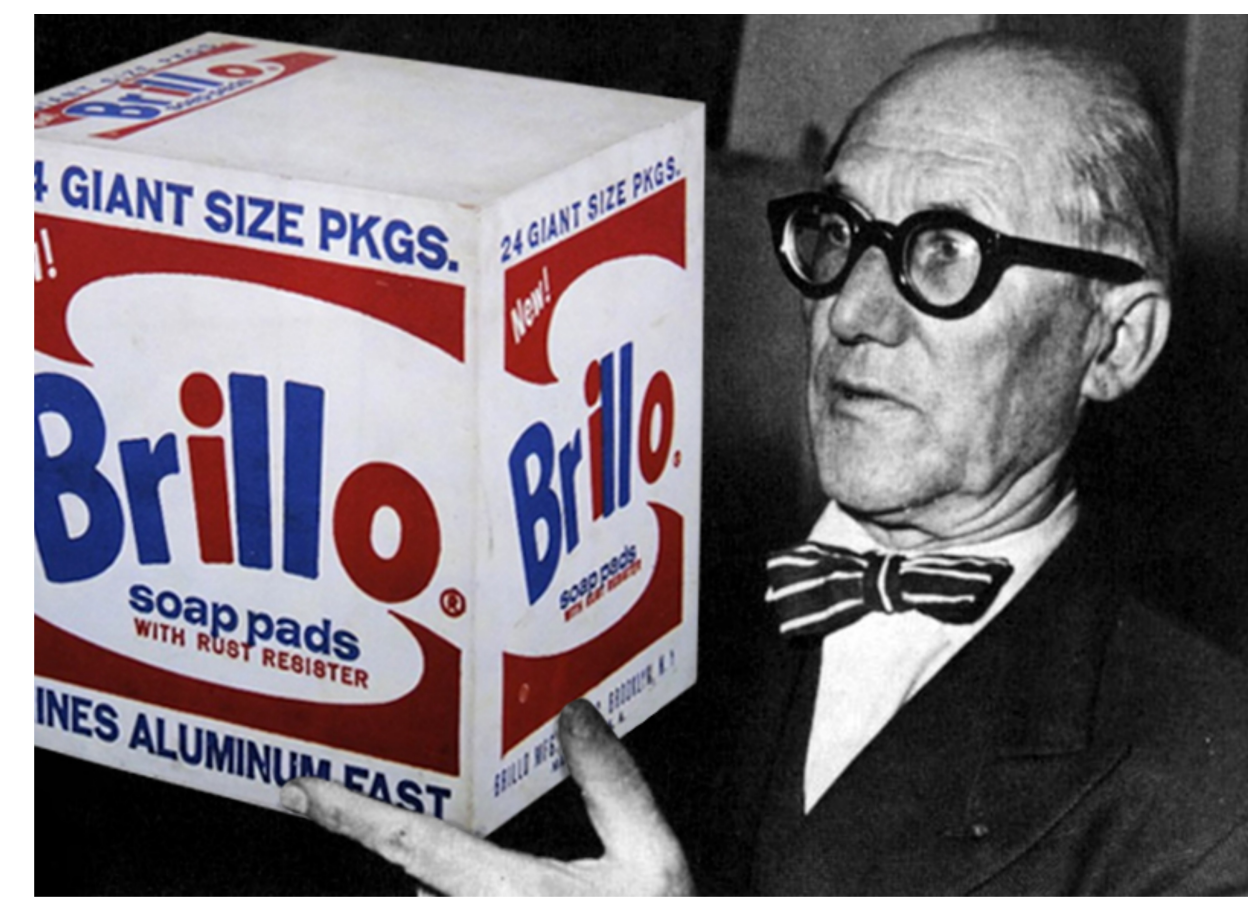

12

A mercadoria resultante dos processos produtivos é imaginada por Le Corbusier como sendo "brilhante, polida e pura", e estes termos mais do que indicarem uma espécie de "fetiche da mercadoria", são reveladores do seu projeto estético insiste-se no fato de que é possivel a fruição estética de objetos produzidos em série, reivindica-se, senão uma transformação do conceito de arte, ao menos uma ampliação deste: deve existir uma espécie de "gozo contemplativo" da mercadoria. Ora, o brilho daquelas superficies polidas é um valor estético porque é o resultado necessário da precisão, do rigor e da exatidão dos processos mecânicos. Em: Lima, "Arquitetura ou revolução": o discurso modernista como ideologia ideológico. ENTECA 2003. IV Encontro Tecnológico da

Figura 17

Brillo. Collage.

Rufino Becker. 2014. Adson Cristiano Bozzi Ramatis, 
Figura 18

Modernidade radiosamente radioativa. Collage. Fernando Fuão. 2018

Figura 20

Le-brillô. Collage. Rufino Becker. 2014. Le Corbusier

Figura 21

A cidade radiosa. Collage. Rufino Becker. 2014

Figura 22

A cidade radiosa. Collage. Rufino Becker. 2014

Ao lado

Figura 19

Diagrama da unidade de Habitação. Le Corbusier

Figura 23

Brillô perspectiva. Collage. Rufino Becker. 2014
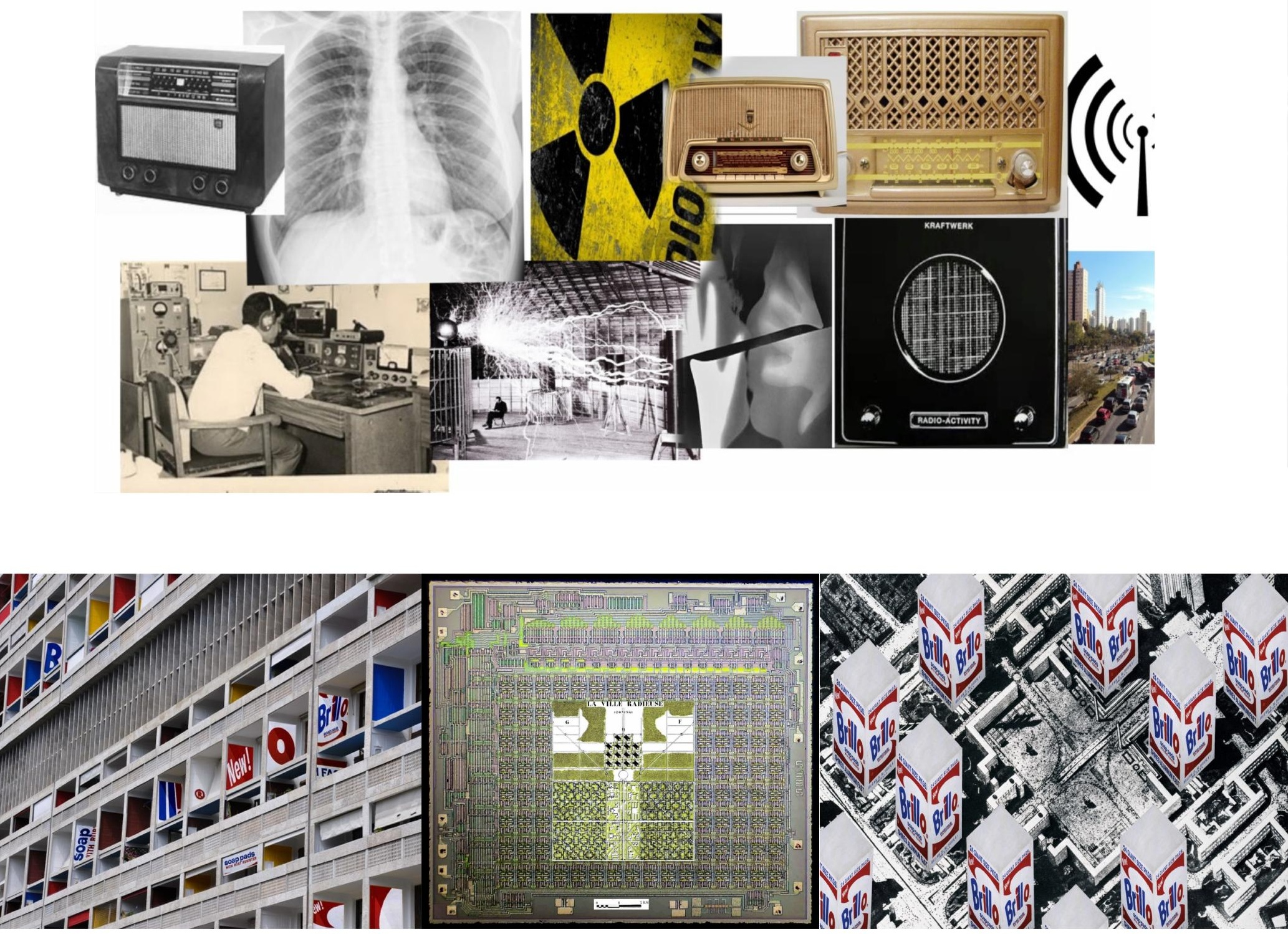
la matemidle<smiles>C1CC1</smiles>

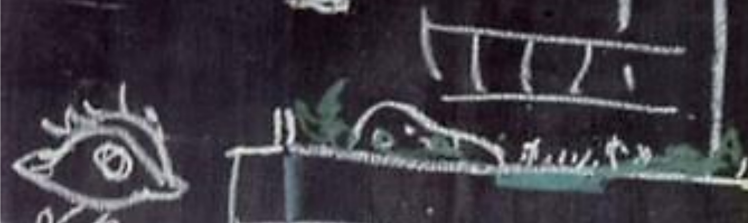

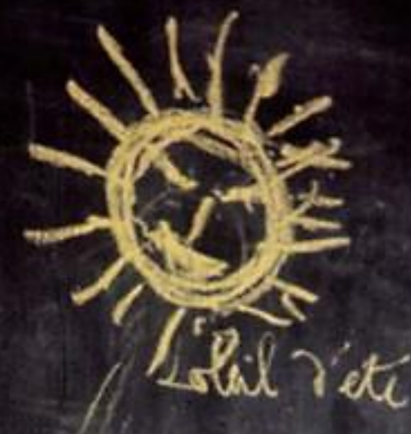

II linats

ach

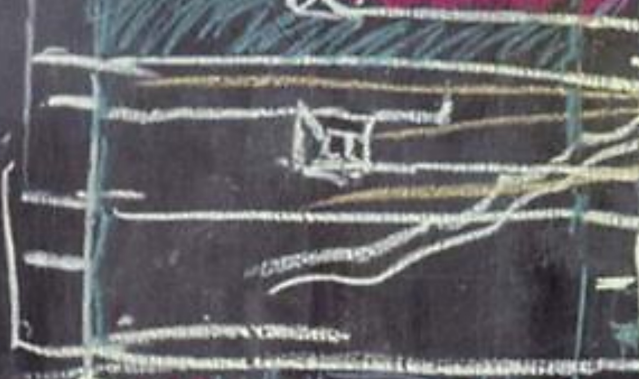

$\rightarrow$ lamontange

Iiis
2 - 11 .
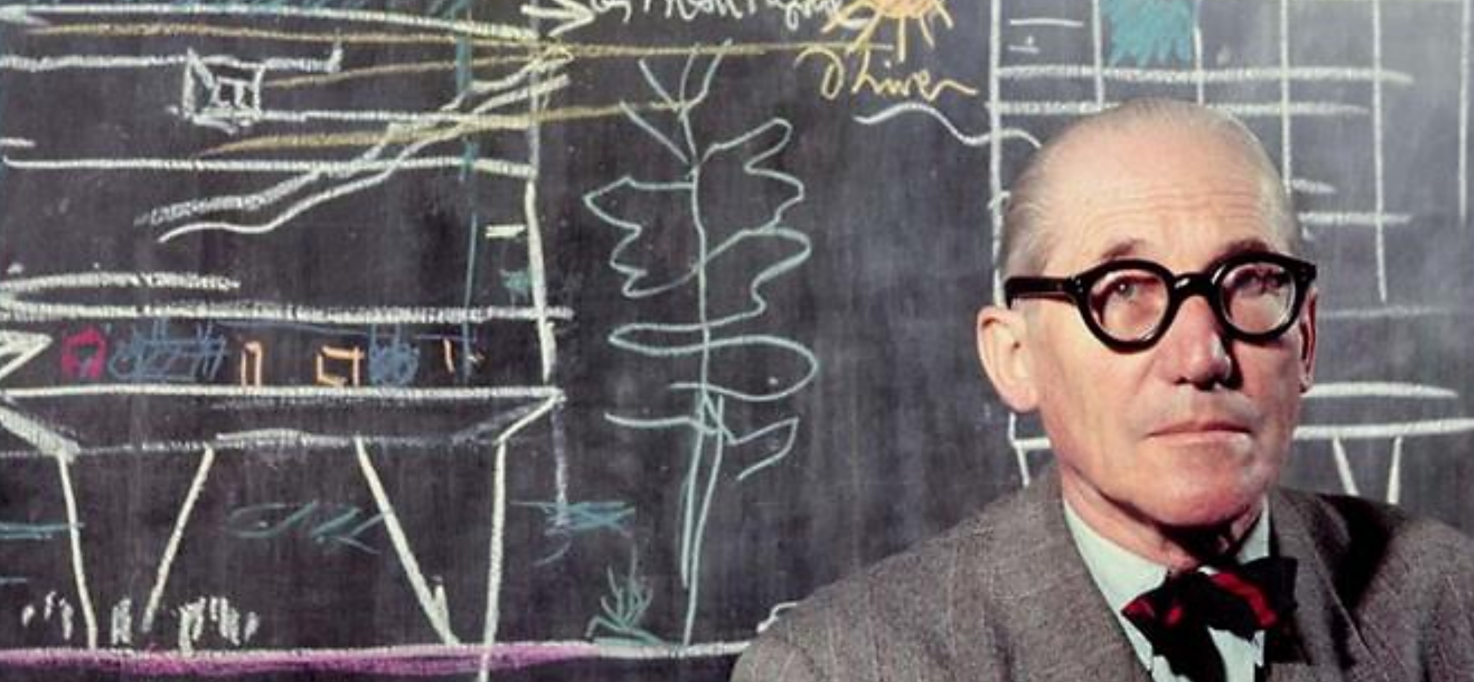

F

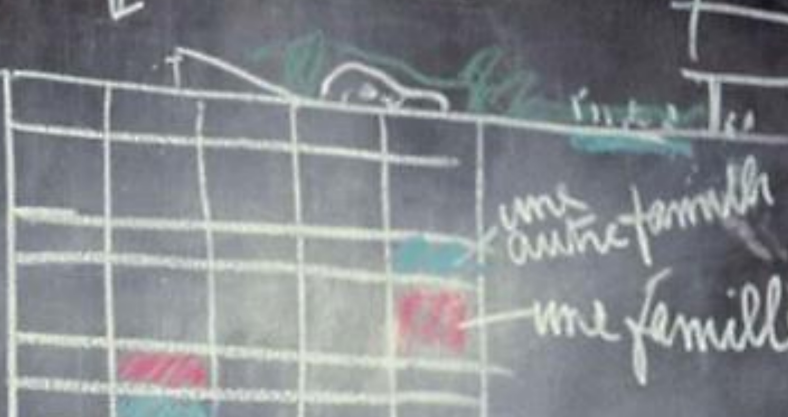


O espectro parece habitar a penumbra, nem no escuro nem no claro, mas na indefinição, no lusco fusco, na bruma, na vaporosidade, no jogo das sombras dos corpos que se despejam uns sobre os outros, nos espelhos. Devemos começar a pensar que a partir da modernidade existe um claro norteamento contra a escuridão, a penumbra que deve ser substituída pela cidade $U R$, a cidade iluminada vinte quatro horas por dia, a casa iluminada envidraçada, a vitrine resplandecente ${ }^{15}$.

A partir do advento do Espírito Novo, a arquitetura e o urbanismo desempenharam não só o papel de um higienismo sanitarista efetuado no corpo da cidade, mas também realizaram uma higienização espectral, literalmente uma defumação na cidade.
Para tal, os arquitetos utilizaram-se de uma série de estratégias arquitetônicas para bani-los de seus locus doméstico como: luminosidade e transparência (envidraçamento), afastamento dos corpos uns dos outros, destituição do quarteirão medieval ou do quarteirão clássico do século XIX, eliminação da propriedade privada da terra nos países comunistas, ou a criação de bairros de conjuntos habitacionais nos países capitalistas. Assim como mostrou Derrida em Espectros de Marx, defendendo que talvez Marx não conseguiu se livrar tão facilmente dos fantasmas como pensava ser possível, estamos convictos que Le Corbusier e os arquitetos modernistas também não conseguiram se livrar tão facilmente dos fantasmas como pensaram ser possível através da higienização

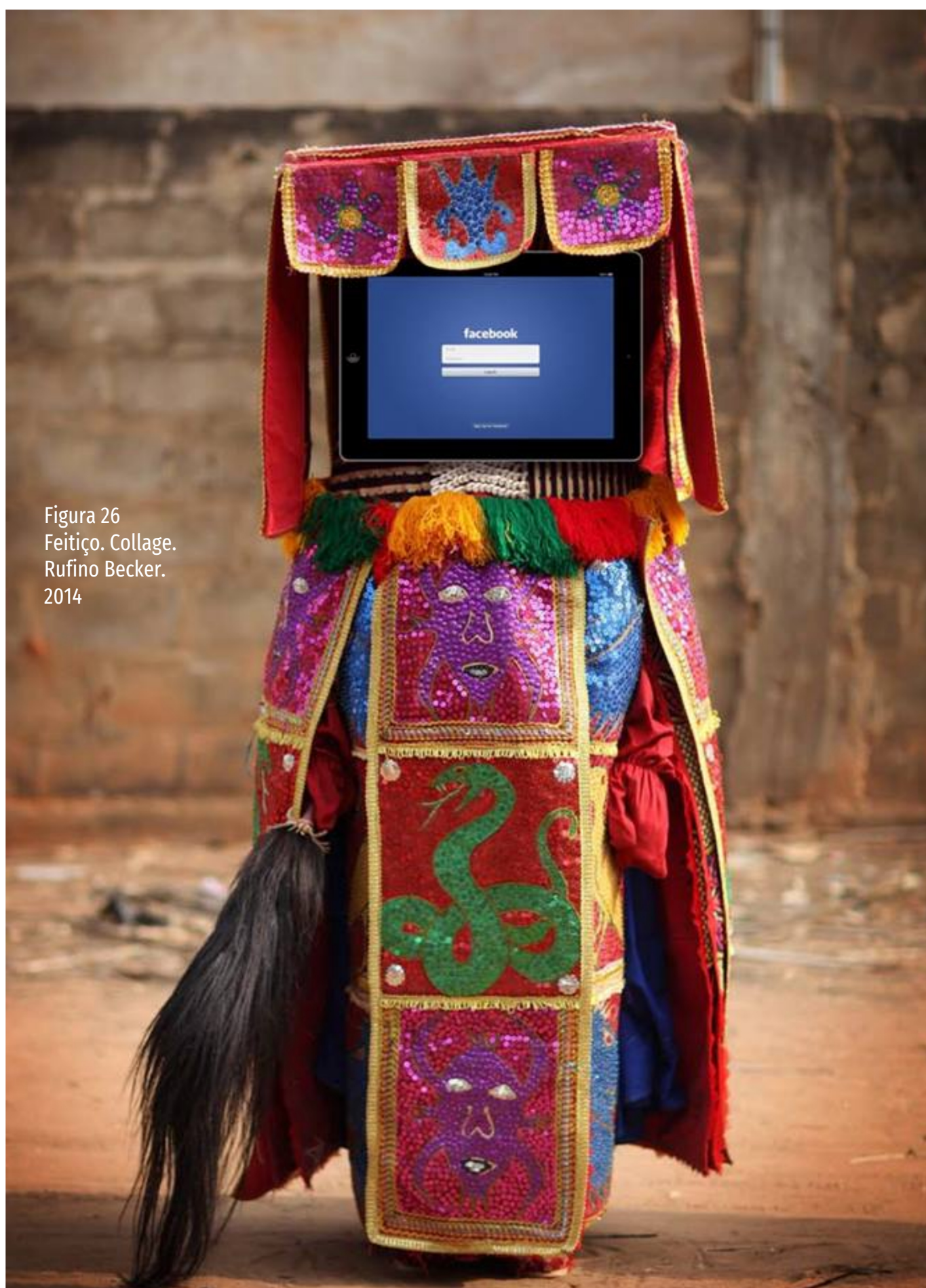

adoravam7 se esconder nos cantos e dobras das paredes, impregná-las.

Fachada Livre: é o resultado da independência da estrutura, cujo objetivo desembocaria também na questão de mais iluminação, graças a ela a fachada pode ser projetada sem impedimentos, e pode se tornar toda envidraçada ou com as janelas rasgadas. Foi preciso tirar a antiga pele do edificio, descasca-lo, ver o que tem dentro, e isso a fachada livre conseguiu fazer como uma radiografia. Um exemplo disso, também é desenho-montagem de Mies para o arranha céu de 1922, que se parece literalmente á uma radiografia (figura 15). Pilotis: ao elevar o prédio do chão Le Corbusier permitia 0 livre deslocamento por debaixo do mesmo, fazia o edificio de certa forma alçar vôo, estabelecia a descontinuidade espacial ascensional da casa e do edificio; em alguns casos eliminando o porão ou conservando-o abaixo do térreo livre. 0 pilotis é talvez um dos elementos mais representativos do acordo implícito entre três agentes: os higienistas, os caça fantasmas e seus intento de acabar com os esconderijos, e principalmente dos comunistas que anseavam a liberação do uso da terra, da propriedade privada como um dos requisitos para a implantação do comunismo. El Lissitzky em seus escritos, assim como outros construtivistas russos, também demonstravam o interesse por uma elevação da arquitetura, uma arquitetura aérea; Hans Sedlmayr retrata bem essa desconjunção, da descentralidade da arte moderna e da arquitetura em seu livro $A$ arte descentrada.

Terraço Jardim: Le Corbusier elimina o sótão e com isso recupera o solo ocupado pelo prédio transferindo-o para cima do prédio na forma de um jardim, assim eliminava o espaço 
onírico das memorias, dos esquecimentos, como nos narra Gaston Bachelard na Poética do Espaço, um dos lugares temidos por nós por ali habitarem espectros familiares e não familiares. Janelas em fita (fenetre longue): consegue graças a fachada livre, permitia uma relação desimpedida com a paisagem, e sobretudo mais iluminação natural nos interiores. De sorte, todos esses princípios estão diretamente ligados a questão da radiação solar. O Sol para Le Corbusier em todos os seus desenhos sempre foi o elemento central atuando diretamente sobre a arquitetura.

Nesse sentido de uma crítica ao excesso de iluminação noturna, veja-se a excelente tese de

Farlley Derze, Cidade á noite: iluminação artificial e modernidade. Universidade de Brasília, Programa de Pesquisa e Pós-graduação da Faculdade de Arquitetura. 2014.

Derrida, J.. Op cit.; p. 10-1 espectral. Tal argumentação, obviamente, era impensável na consciência da maioria dos arquitetos da época. Eles acreditavam no seu trabalho em cima dos postulados modernistas, que nada tinham a ver com a questão dos espectros, fantasmas e antepassados.

Os espectros e fantasmas foram deslocados para outros receptáculos; houve sim o deslocamento e uma contenção dentro de lugares destinados à apreciação deles como as salas de cinema, teatros, televisões, nos vídeo games, celulares, nas câmaras de vigilância, nas torres de observação. Os antigos lugares que outrora habitavam e vagavam os fantasmas foram e seguem exaustivamente explorados nos filmes de suspense e de terror. Hoje, se existem lugares permitidos para os espectros e fantasmas estes também se tornaram obviamente mercadorias, fantasmagorias. Segundo Benjamin, pagamos para ser assediados momentaneamente, pagamos para sentir medo: eis aí a crueldade do capitalismo. Adultos e crianças divertem-se temporariamente, vivendo a loucura produzida como espetáculo. Os espectros e fantasmas estão trancafiados nesses espaços e em nossas cabeças, exatamente como a loucura era trancafiada nos manicômios, estão contidos no mesmo modelo de exclusão e confinamento, a mesma prática que fundou e que se instalou sobre os corpos na cidade pestilenta no século XVIII e XIX. A domesticação espectral.

Hoje a questão espectral está por tudo; caminhamos na rua falando sozinhos com espectros ao celular, vivemos e trabalhamos em novas arquiteturas espectrais. Retiramos os espectros da arquitetura, mas ironicamente transformamos a própria arquitetura num objeto espectral, fantasmático, especular. A lógica dos espectros e das visitações (hontologique) se aproxima da lógica da superstição (superestrutura), não no sentido pejorativo, mas num tipo de lógica ainda presente na sociedade, que Derrida denomina lógica espectral. Quando Derrida abre Espectros de Marx, de certa forma está nos mostrando a espectralidade que vivemos. Ele reafirma os nossos temores espectrais, propondo-nos rever a cidade pela lógica espectral dos retornantes. Com Espectros de Marx, Derrida abriu a porta da academia para a entrada de uma legião de espectros para nos despertar, assombrar. Ao apresentar o acontecimento espectral, ele esta sobretudo nos fazendo ver a realidade virtual e da presença contínua dos espectros políticos. $\mathrm{Na}$ verdade, eles estão aí mesmo; independente de nosso querer, eles seguem nos comandando. Talvez seja melhor, como disse Derrida, reaprender a reconhecêlos, conversar com eles, negociar para que permaneçam onde estão; fazer conjuro e desconjuros, aceitar certas heranças e rejeitar outras heranças.

Eu queria aprender a viver, aprender a viver entre vida e morte. Nem na vida nem na morte apenas. O que se passa entre os dois, e entre todos 'os dois' que se queiram, só pode ter sentido se valer de algum fantasma. O tempo do 'aprender a viver', um tempo sem presente tutor, consistiria nisto: aprender a viver com os fantasmas, no encontro, na companhia ou no corporativismo, no comércio sem comércio dos fantasmas. A viver de outro modo, e melhor. Talvez não melhor, mas mais justamente. Mas com eles. E este estar-com os espectros seria também, não somente, mas também uma política da memória, da herança e das gerações ${ }^{16}$. 


\section{LISTA DAS FIGURAS}

Figura 1. Collage do autor

Figura 2. https://quotesgram.com/the-raven-edgarallan-poe-quotes/

Figura 3. http://iala1415gb03.blogspot.com/2015/01/

Figura 4.

https://criticadeartebh.com/2017/01/16/capa-de-

lesprit-nouveau-no1-1920/

Figura5.

https://quod.lib.umich.edu/a/aict/xrm062/RM000_IM

G0062?lasttype=boolean;lastview=thumbnail;med $=1 ; r$

esnum=859;size=20;sort=aict_ti;start=841;subview=de

tail;view=entry;rgn1=ic_all;q1=aict

Figura 6. Collage do autor

Figura 7.

http://garyhill.com/work/mixed_media_installation/ibelieve-it-is-an-image.html

Figura 8. Collage do autor

Figura 9. Collage do autor

Figura 10. http://arquitetura-

rte.blogspot.com/2010/05/

Figura 11. Collages de Rufino Becker

Figura 12. Collage do autor

Figura 13. Rowe, Colin; Koetter, fred. Collage city.

Editorial Gustavo Gili. Barcelona 1981. P. 137

Figura 14. Collage do autor

Figura 15. Collage do autor

Figura 16. Foto do autor

Figura 17. Collage de Rufino Becker

Figura 18. Collage do autor

Figura 19. http://www.scrivonapoli.it/giornata-distudi-in-ricordo-di-le-corbusier/

Figura 20. Collage de Rufino Becker

Figura 21. Collage de Rufino Becker

Figura 22. Collage de Rufino Becker

Figura 23. Collage de Rufino Becker

Figura 24. Collage do autor

Figura 25. Collage do autor

Figura 26. Collage de Rufino Becker

\section{REFERENCIAS \\ BIBLIOGRÁFICAS}

BACHELARD, Gaston. A Poética do Espaço. Em:

Bachelard. Coleção Os pensadores. São Paulo. Abril

Cultural. 1978.

BROTT, Simone. Architecture et révolution: Le Corbusier and the fascist revolution. Thresholds 41. Spring 2013, p. 146-157. Disponível em:

https://docplayer.net/48734962-Architecture-etrevolution-le-corbusier-and-the-fascist-revolutionsimone-brott.html

COLOMINA, Beatriz. La domesticidade en guerra. Actar. Barcelona, 2006.

COULANGES. Fustel de. A cidade antiga. São Paulo. Martins Fontes. 1981.

DERRIDA, J. Espectros de Marx. O estado da dívida, o trabalho do luto e a nova Internacional. Rio de Janeiro. Relume Dumará. 1994. Tradução Anamaria Skinner.

DERZE, Farlley. Cidade à noite: iluminação artificial e modernidade. Universidade de Brasília, Programa de Pesquisa e Pós-graduação da Faculdade de Arquitetura. 2014.

ENGELS, Friedrich. A Situação da classe trabalhadora em Inglaterra. Porto. Edições Afrontamento. 1975.

. A Origem da Família, da

Propriedade Privada e do Estado. São Paulo. Editora Global. 1984

FOUCAULT, Michel. Vigiare Punir. Petrópolis. Editora Vozes. 1977. 
FUÃO, F.: Querências de Derrida. Em Arquitetura e Filosofia da desconstrução. Coleção Querências de Derrida, moradas da arquitetura e filosofia. Porto Alegre, 2015. Ufrgs. Cnpq. Capes

FUÃO, F.; Viecelli, A.: A porta. Em: A porta, a ponte, o buraco, um orelhão. Coleção Querências de Derrida, moradas da arquitetura e filosofia. Porto Alegre, 2015. Ufrgs. Cnpq. Capes

LE CORBUSIER. Vers une architecture. 2.ed. Les Éditions G. CRÈS, 1924, Paris, p. 6.

Por uma arquitetura. São Paulo. Editora Perspectiva. 1983.

A Carta de Atenas. São Paulo. Hucitec. 1993. Tradução e apresentação de Roberta Scherer.

LIMA, Adson Cristiano Bozzi Ramatis, "Arquitetura ou revolução": o discurso modernista como ideologia ideológico. ENTECA 2003. IV Encontro Tecnológico da Engenharia Civil e Arquitetura. Universidade de Maringá. Maringá. Disponível em:

http://www.dec.uem.br/eventos/enteca_2003/Temas/ tema1.htm
MARX, K.; ENGELS, F.. A ideologia alemã. São Paulo. Boitempo Editorial. 2007

OManifesto Comunista. São

Paulo. Instituto José Luís e Rosa

SIRET, Daniel Siret. L'illusion du brise-soleil par Le Corbusier. Colloque langages scientifiques et pensée critique : modélisation, environnement, décision publique, Jun 2002, Cerisy, France. Disponível em: https://docplayer.fr/52111304-L-illusion-du-brisesoleil-par-le-corbusier.html

SLOTERDIJK, Peter. Esferas 3. Espumas. Barcelona. Ed. Siruela. 2003.

Sundermann. 2003

SEDLMAYR, Hans. A arte descentrada. Barcelona. Editorial Labor. 1959.

STIRNER, MAX. O único e sua propriedade. Lisboa. Antígona e João Barrento. 2004 